\title{
Effect of natural auxin from portulaca grandiflora hook and Ipomoea batatas (L.) Poir on the formation adventitious roots in vitro of Plumbago zeylanica $L$.
}

\author{
Nguyen Tran Dong Phuong ${ }^{1 *}$, Tran Thi Xuan Huong ${ }^{1}$ \\ ${ }^{1}$ Ho Chi Minh City Open University, Vietnam \\ *Corresponding author: nguyentrandongphuong@gmail.com
}

\begin{tabular}{|c|c|}
\hline ARTICLE INFO & ABSTRACT \\
\hline $\begin{array}{l}\text { DOI:10.46223/HCMCOUJS. } \\
\text { tech.en.8.2.344.2018 }\end{array}$ & $\begin{array}{l}\text { Plumbago zeylanica L. is a traditional herbal that has been } \\
\text { reported to treat skin diseases. Furthermore, some researchers } \\
\text { have found plumbagin extracted from the roots of this species can } \\
\text { prevent cancer cell development. In current study, stems of } \\
\text { Plumbago zeylanica L. were cultured on MS medium with BA } 1.0\end{array}$ \\
\hline Received: February $6^{\text {th }}, 2018$ & $(0.01-0.15 \mathrm{mg} / \mathrm{L})$ or NAA $(0.1-0.15 \mathrm{mg} / \mathrm{L})$. After \\
\hline Revised: May $8^{\text {th }}, 2018$ & 8-week cultured, stems were transferred to MS medium with \\
\hline Accepted: May $14^{\text {th }}, 2018$ & $\begin{array}{l}\text { extracted trom stems of Portulaca grandiflora Hook }(2-10 \mathrm{ml} / \mathrm{L}) \\
\text { or extracted from stems of Ipomoea batatas }(\mathrm{L} \text {.) Poir. The results } \\
\text { showed that the appropriate medium for shoot formation was in } \\
\text { MS with BA and IAA } 0.1 \mathrm{mg} / \mathrm{L} \text { or NAA } 0.1 \mathrm{mg} / \mathrm{L} \text {. The } \\
\text { adventitious roots in vitro were formatted in MS medium supplied } \\
\text { with extracted from stems Portulaca grandiflora Hook or from }\end{array}$ \\
\hline$K$ & stems of Ipomoea batatas (L.) Poir 6 ml/L. Simultaneously, after \\
\hline $\begin{array}{l}\text { adventitious roots, Ipomoea } \\
\text { batatas }(\mathrm{L} .) \text { Poir, plumbago } \\
\text { zeylanica } \text { L., plumbagin, } \\
\text { portulaca grandiflora hook }\end{array}$ & $\begin{array}{l}\text { 8-week cultured, the adventitious roots were collected and } \\
\text { plumbagin qualitative were analyzed with pure plumbagin of } \\
\text { Sigma. As the result, plumbagin presents in adventitious roots } \\
\text { cultured. }\end{array}$ \\
\hline
\end{tabular}

\section{Introduction}

Plumplings called Plumbago zeylanica L., belonging to the Plumbaginaceae family, are a medicinal plant originating from Northwest Asia, grown in India, West Bengal, tropical Africa and some countries in Southeast Asia, including Malaysia, Philippines, Thailand, Laos, Cambodia, Indonesia (Dang et al., 2006). Plumbago zeylanica L. is found only to cure skin diseases, ulcers, wounds in humans (Nguyen \& Le, 2000). The roots contain a crystalline acridine called plumbagin, a yellow naphthoquinone used as a drug in India from $750 \mathrm{BC}$. It is used for parasitic resistance, cardioprotection, liver protection, and neurodevelopment. In addition, many different active ingredients have been identified in these plant roots, including phenolic acids, tannins, anthocyanins, etc. (Tran, 2003). This is a substance that inhibits the growth of Gram-positive bacteria (Staphylococcus, Streptococcus and Pneumococcus), anti- 
cancer, antioxidant, anti-malaria. It also has anti-inflammatory, anticoagulant effect in white rats, treatment at the beginning of the disease and baldness.

Plumbago zeylanica L. grow slowly in natural conditions, the roots of plants used to acquire plumbagin need many years for high levels of active ingredients (Quach, 2012). In Vietnam, it is grown both wild and newly planted in some places (Quach, 2012). Therefore, the problem is that if harvesting in the wild, it is necessary to remove the plant so it is very costly and time-consuming to regenerate the material. The use of synthetic growth regulators will have an influence on the biologically active substances that plants synthesize during growth. Therefore, we use Portulaca grandiflora Hook or Ipomoea batatas (L.) Poir extracts as natural auxin source which are beneficial for the purpose of producing adventitious roots, contributing to a safe source of raw materials, increasing efficiency in pharmaceuticals, cost-effective and environmentally friendly.

\section{Material and method material}

\section{Plumbago zeylanica L., Portulaca grandiflora}

Hook and Ipomoea batatas (L.) Poir were collected from the herbal garden in Open University of Ho Chi Minh City.

\subsection{Method}

Stems of Plumbago zeylanica L. were accepted with alcohol $70 \%$ for 3 minutes, followed by soaking in $\mathrm{Ca}(\mathrm{OCl}) 215 \%$ for 15 minutes and washing three times with sterile distilled water. After that, the stems were cut into short sections $1.0-1.5 \mathrm{~cm}$ with dormant buds and cultured on MS medium supplied with BA $1 \mathrm{mg} / \mathrm{L}$ and IAA $(0.01,0.05,0.10,0.15 \mathrm{mg} / \mathrm{L})$ or NAA $(0.01,0.05,0.10,0.15 \mathrm{mg} / \mathrm{L})$. After 8 -week culture, stems in vitro in experiments before were transferred to MS medium supplied Portulaca grandiflora Hook or Ipomoea batatas (L.) Poir extracts at the concentration of $0-10 \mathrm{ml} / \mathrm{L}$. The $\mathrm{pH}$ of the medium was adjusted to 5.8 , and then autoclave at $121^{\circ} \mathrm{C}, 1 \mathrm{~atm}$ pressure for 30 minutes. The cultures were incubated at $22 \pm$ $2^{\circ} \mathrm{C}$ under a light intensity of 2,000 3,000 lux, with a photoperiod of 12/12 light/dark. $25 \mathrm{~g}$ fresh roots from experiments in vitro were sliced and soaked with $50 \mathrm{~mL}$ diethyl ether supplied $1 \% \mathrm{H} 2 \mathrm{SO} 4$ overnight. The extract was filtered, plus $25 \mathrm{~mL} \mathrm{H} 2 \mathrm{SO} 42 \mathrm{M}$ and incubated at $50^{\circ}$ C. The solvent was removed and collected the extract and quality plumbagin by thin-layer chromatography (TLC). The extract from experiments was plus with $1 \mathrm{~mL}$ chloroform, pointed on TLC silica gel $60 \mathrm{~F} 254(5 \mathrm{x} 12 \mathrm{~cm})$, and put the TLC on the solvent including petroleum ether: ethyl acetate (6:3) and compared with pure plumbagin of Sigma under ultraviolet lightwave $254 \mathrm{~nm}$.

\subsection{Statistical analysis}

All experiments were designed in a completely randomized form. Each experiment was repeated 4 times, data were processed by software Statgraphics Plus 3.0 Duncan Multiple Range Test (Duncan, 1955) at $\mathrm{p}<0.05$. 


\section{Results}

\section{Effect of phytohormones on shoot formation}

The result in table 1 and figure 1 showed that MS medium with BA $1.0 \mathrm{mg} / \mathrm{L}$ and IAA $0.10 \mathrm{mg} / \mathrm{L}$ or BA $1.0 \mathrm{mg} / \mathrm{L}$ and NAA $0.10 \mathrm{mg} / \mathrm{L}$ have the best effect on the number and height of shoot of Plumbago zeylanica L. But if the concentration of IAA or NAA is less or more than $0.10 \mathrm{mg} / \mathrm{L}$, the number of the shoot will be reduced.

\section{Table 1}

Effect of phytohormones on shoot formation after 8-week culture

\begin{tabular}{|l|c|c|}
\hline \multicolumn{1}{|c|}{ Experiment } & Shoot number & Shoot height $(\mathbf{c m})$ \\
\hline Control & $1.50^{\mathrm{b}}$ & $1.57^{\mathrm{b}}$ \\
\hline (BA 1.00 and IAA $0.01 \mathrm{mg} / \mathrm{L})$ & $1.67^{\mathrm{b}}$ & $1.35^{\mathrm{b}}$ \\
\hline (BA 1.00 and IAA $0.05 \mathrm{mg} / \mathrm{L})$ & $3.50^{\mathrm{a}}$ & $1.52^{\mathrm{b}}$ \\
\hline (BA 1.00 and IAA $0.10 \mathrm{mg} / \mathrm{L})$ & $3.50^{\mathrm{a}}$ & $2.25^{\mathrm{a}}$ \\
\hline (BA 1.00 and IAA $0.15 \mathrm{mg} / \mathrm{L})$ & $1.17^{\mathrm{b}}$ & $1.38^{\mathrm{b}}$ \\
\hline (BA 1.00 and NAA $0.01 \mathrm{mg} / \mathrm{L})$ & $1.33^{\mathrm{c}}$ & $1.25^{\mathrm{bc}}$ \\
\hline (BA 1.00 and NAA $0.05 \mathrm{mg} / \mathrm{L})$ & $2.33^{\mathrm{bc}}$ & $1.45^{\mathrm{b}}$ \\
\hline (BA 1.00 and NAA $0.10 \mathrm{mg} / \mathrm{L})$ & $3.67^{\mathrm{a}}$ & $2.33^{\mathrm{a}}$ \\
\hline (BA 1.00 and NAA $0.15 \mathrm{mg} / \mathrm{L})$ & $2.00^{\mathrm{bc}}$ & $1.33^{\mathrm{bc}}$ \\
\hline
\end{tabular}

Source: The researcher's data analysis 

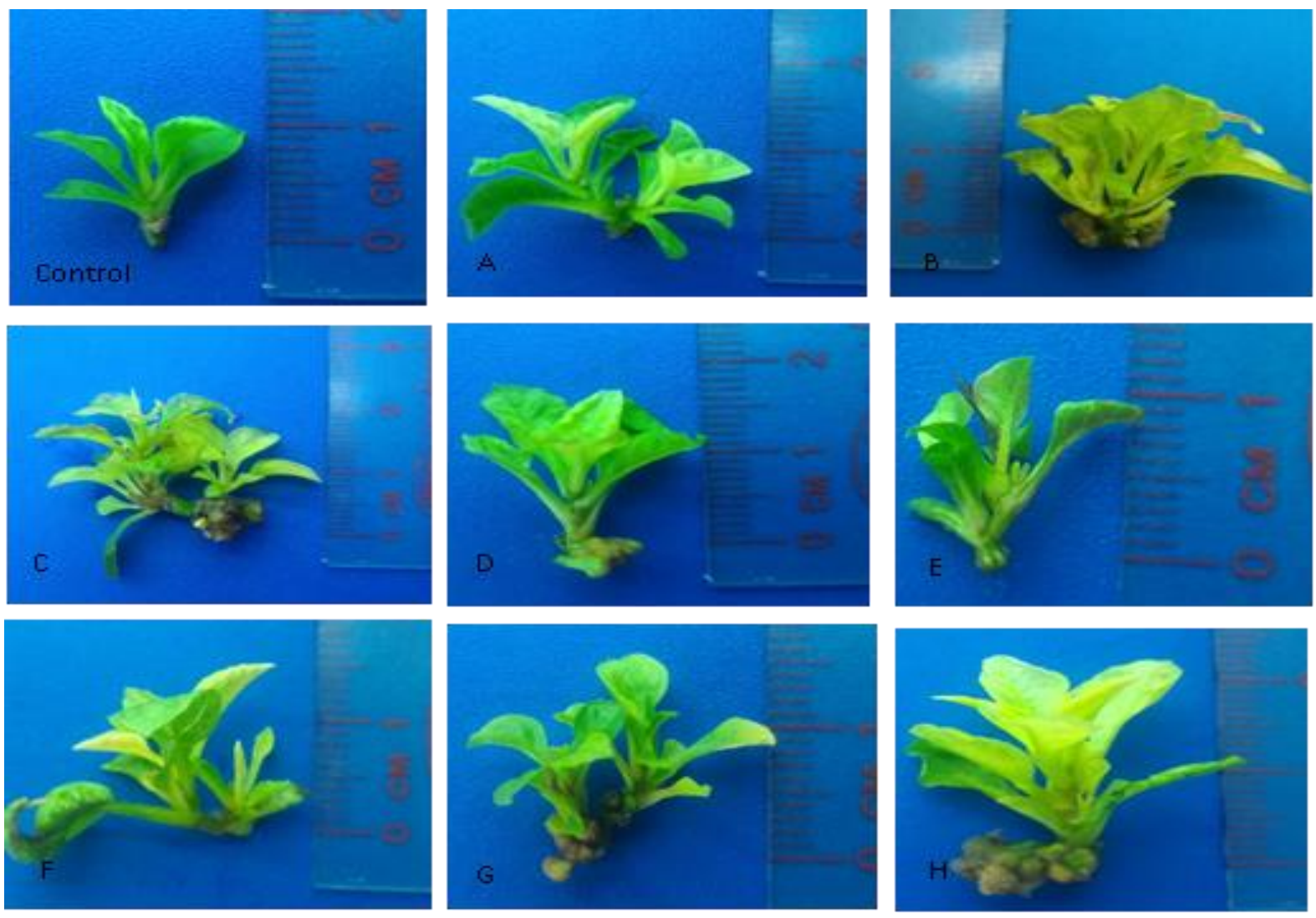

Figure 1. Effect of phytohormones on shoot formation after 8-week culture

Note: A-D: BA $1.00 \mathrm{mg} / \mathrm{L}$ and IAA (0.01-0.15 mg/L), E-H: BA $1.00 \mathrm{mg} / \mathrm{L}$ and NAA (0.01-0.15 mg/L)

Effect of the concentration Concentration of grandiflora Hook extract on the ability of root formation from the stem of zeylanica $\mathrm{L}$.

The results in table 2 and figure 2 showed that different levels of Portulaca grandiflora Hook extract have different effects on root formation and morphological characteristics of roots. After 8 weeks of culture, medium supplemented with Portulaca grandiflora Hook extracts $6 \mathrm{ml} / \mathrm{L}$ had the highest rooting rate was 336.25 roots/stem, the root length was $4.50 \mathrm{~cm}$. However, the extract of Portulaca grandiflora Hook was higher or less than $6 \mathrm{ml} / \mathrm{L}$ had a negative effect.

\section{Table 2}

Effect of the extracted of Portulaca grandiflora Hook the ability root formation from stem Plumbago zeylanica L.

\begin{tabular}{|c|c|c|}
\hline $\begin{array}{c}\text { Portulaca grandiflora Hook extract } \\
\text { concentration (ml/L) }\end{array}$ & $\begin{array}{c}\text { Root length } \\
(\mathbf{c m})\end{array}$ & Root number \\
\hline Control & $2.35^{\mathrm{bc}}$ & $51.00^{\mathrm{c}}$ \\
\hline
\end{tabular}




\begin{tabular}{|c|c|c|}
\hline $\begin{array}{c}\text { Portulaca grandiflora Hook extract } \\
\text { concentration }(\mathbf{m l} / \mathrm{L})\end{array}$ & $\begin{array}{c}\text { Root length } \\
(\mathbf{c m})\end{array}$ & Root number \\
\hline 2 & $2.13^{\mathrm{c}}$ & $81.50^{\mathrm{bc}}$ \\
\hline 4 & $2.88^{\mathrm{b}}$ & $121.25^{\mathrm{b}}$ \\
\hline 6 & $4.50^{\mathrm{a}}$ & $336.25^{\mathrm{a}}$ \\
\hline 8 & $2.63^{\mathrm{bc}}$ & $115.75^{\mathrm{b}}$ \\
\hline 10 & $1.40^{\mathrm{d}}$ & $30.625^{\mathrm{c}}$ \\
\hline
\end{tabular}

Source: The researcher's data analysis
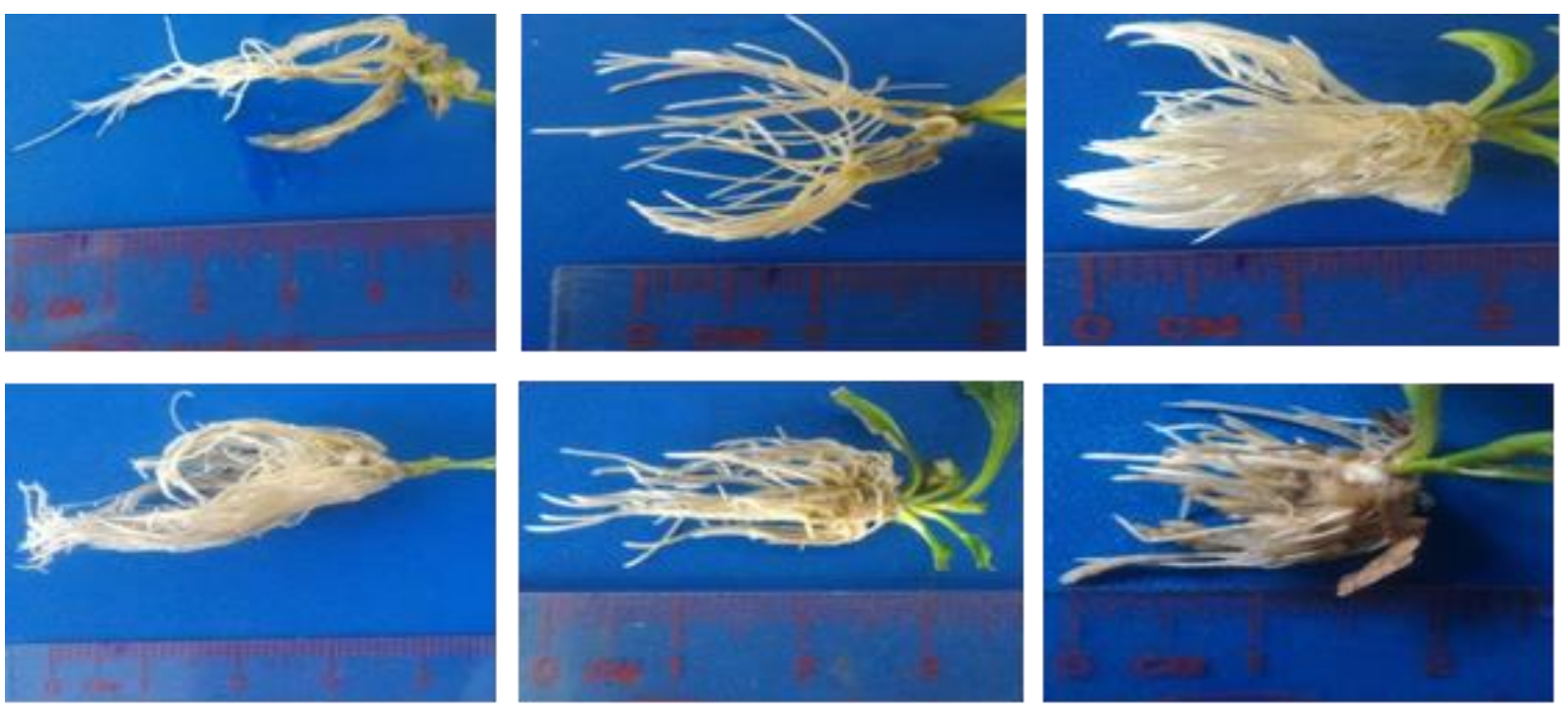

Figure 2. Roots of Plumbago zeylanica L. after 8-week culture in MS medium supplied extract from Portulaca grandiflora Hook Control A, B, C, D, E: 2, 4, 6, 8, 10 (ml/L)

The effect of Ipomoea batatas (L.) Poir extract on the ability of root formation from the stem of Plumbago zeylanica $\mathrm{L}$

The results in table 3 and figure 3 showed that different levels of Ipomoea batatas (L.) Poir extract has different effects on root formation and morphological characteristics of roots. After 8 weeks of culture, the results showed that in MS medium supplied with Ipomoea batatas (L.) Poir extract concentrations of $6 \mathrm{ml} / \mathrm{L}$, the highest root rate was 599.75 roots/stem, the root length was $7.25 \mathrm{~cm}$. 


\section{Table 3}

Effect of the extracted concentration of batatas (L.) Poir the ability of root formation from stem Plumbago zeylanica L.

\begin{tabular}{|l|l|l|}
\hline $\begin{array}{l}\text { Ipomoea batatas (L.) Poir extract } \\
\text { concentration (ml/L) }\end{array}$ & Root length $(\mathrm{cm})$ & Root number \\
\hline Control & $2.15^{\mathrm{c}}$ & $62.75^{\mathrm{c}}$ \\
\hline 2 & $2.40^{\mathrm{bc}}$ & $139.75^{\mathrm{b}}$ \\
\hline 4 & $3.50^{\mathrm{b}}$ & $121.25^{\mathrm{b}}$ \\
\hline 6 & $7.25^{\mathrm{a}}$ & $599.75^{\mathrm{a}}$ \\
\hline 8 & $2.50^{\mathrm{bc}}$ & $115.75^{\mathrm{b}}$ \\
\hline 10 & $1.75^{\mathrm{c}}$ & $68.75^{\mathrm{c}}$ \\
\hline
\end{tabular}

Source: The researcher's data analysis
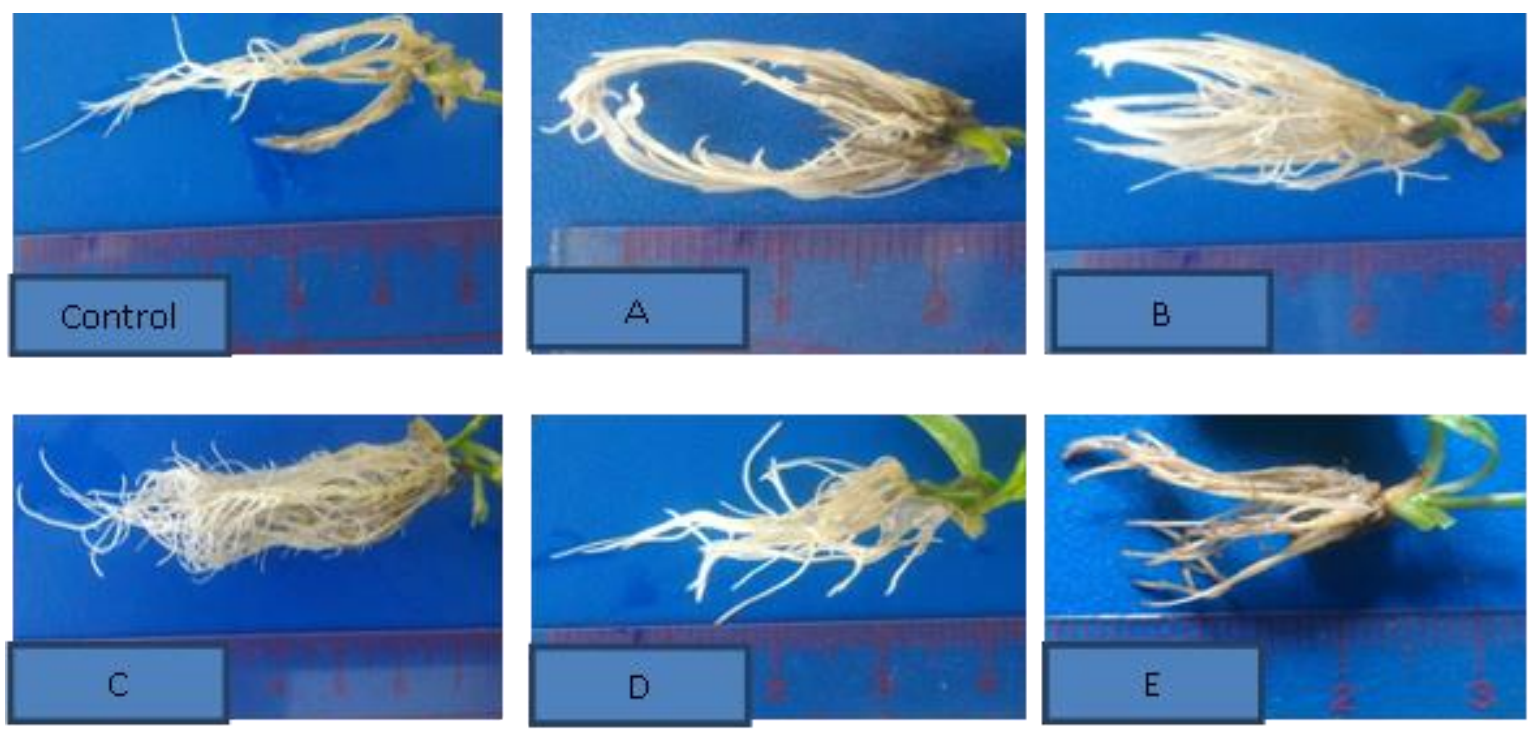

Figure 3. Roots of Plumbago zeylanica L. after 8-week culture in MS medium supplied extract from Ipomoea batatas (L.) Poir Control A, B, C, D, E: 2, 4, 6, 8, 10 (ml/L)

Determination of plumbagin from the adventitious root extract of Plumbago zeylanica $\mathrm{L}$ in vitro

The adventitious root extract of Plumbago zeylanica L from rooting experiments had plumbagin as well as pure plumbagin at Rf 6.5 (Figure 4). 


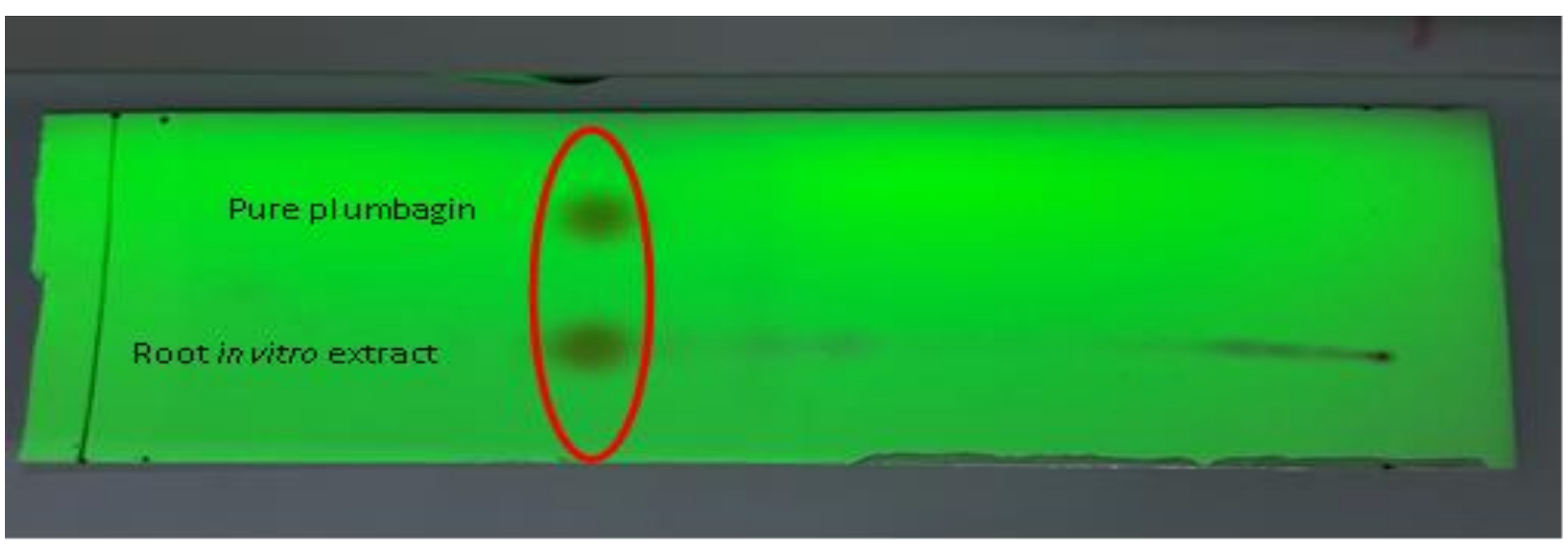

Figure 4. Products extracted in the chromatography system is solvent petroleum ether: ethyl acetate (6: 3) with pure plumbagin of Sigma and root in vitro extract

\section{Discussion}

In this research, the combination of auxin (IAA or NAA $0.1 \mathrm{mg} / \mathrm{L}$ ) and cytokinin (BA $1.0 \mathrm{mg} / \mathrm{L}$ ) affect shoot formation in Plumbago zeylanica $\mathrm{L}$. stem in vitro. Phytohormones are signal molecules that individually or cooperatively direct the development of individual cells or carry information between cells and thus coordinate growth and development. Auxin is characterized principally by their capacity to stimulate cell elongation in excised stem and coleoptile sections, but they also influence a host of other developmental responses, including root initiation, vascular differentiation, tropic responses, and the development of axillary buds, flowers and fruit. Cytokinins are characterized primarily by their ability, in combination with auxin, to stimulate cell division, or cytokinesis, in tissue culture. In addition to stimulating cell division, cytokinins also influence shoot and root differentiation in tissue culture, the growth of lateral buds and leaf expansion, chloroplast development and leaf senescence (Hopkins \& Huner, 2004).

The extract from Portulaca grandiflora Hook and Ipomoea batatas (L.) Poir can use as an auxin source to influence root formation in stem culture. Which are beneficial for the purpose of producing adventitious roots, contributing to a safe source of raw materials, increasing efficiency in pharmaceuticals, cost-effective and environmentally friendly.

\section{Conclusion}

Micropropagation Plumbago zeylanica L. shoot achieved when stem culture on MS medium plus BA $1.0 \mathrm{mg} / \mathrm{L}$ and IAA 0.10 or BA $0.1 \mathrm{mg} / \mathrm{L}$ and NAA $0.10 \mathrm{mg} / \mathrm{L}$. Portulaca grandiflora Hook and Ipomoea batatas (L.) Poir extract at $6 \mathrm{ml} / \mathrm{L}$ can be used to replace auxin in adventitious root formation of Plumbago zeylanica L. The extraction from the adventitious root of Plumbago zeylanica L. content plumbagin. 


\section{References}

Dang, C. Q., Do, B. H., Bui, C. X., Nguyen, D. T., Do, D. T., Pham, H. V., ... Tran, T. (2006). Cay thuoc va dong vat lam thuoc o Vietnam [Medicinal plants and medicinal animals in Vietnam]. Hanoi, Vietnam: NXB Khoa hoc va Ky thuat.

Duncan, D. B. (1955). Multiple range and multiple F tests. Biometrics, 11(1), 1-42.

Hopkins, W. G., \& Huner, N. P. A. (2004). Plant physiology (3th ed.). Hoboken, NJ: John Wiley \& Son, Inc.

Nguyen, L. D., \& Le, T. T. T. (2000). Cong nghe te bao thuc vat [Plant cell technology]. Ho Chi Minh, Vietnam: NXB Dai hoc Quoc gia Tp. Ho Chi Minh.

Quach, P. N. D. (2012). Thu nghiem cam ung tao re in vitro va re to cay Bach Hoa Xa (Plumbago zeylanica Linn) nham thu nhan Plumbagin [Induction of in vitro rooting and silk root of Plumbago zeylanica Linn to obtain Plumbagin]. Paper presented at the Vietnam National University Ho Chi Minh City - University of Science, Ho Chi Minh, Vietnam.

Tran, T. N. B. (2003). Nghien cuu ly trich va dieu che dan xuat tu re cay bach hoa xa [Research on extracting and preparation derivative of Plumbago zeylanica Linn] (Unpublished master's thesis). Vietnam National University Ho Chi Minh City - University of Science, Ho Chi Minh, Vietnam. 